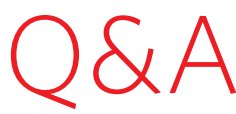

宇宙論

\title{
Dark matter and dark energy
}

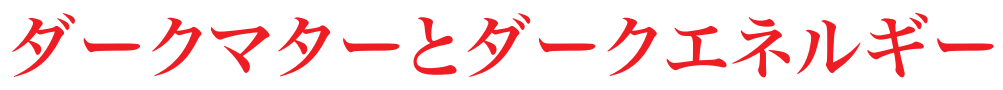

\section{Robert Caldwell \& Marc Kamionkowski}

Nature Vol.458(587-589)/2 April 2009

宇宙の大部分が私たちの目に見えないダークマターとダークエネルギーによって占められていることを、さまざまな 観測結果が示唆し続けている。この宇宙の闇を解明することは、天文学者と物理学者にとつて重要な課題である。

宇宙はどのような成分から成り立っているのか ?

平均エネルギー密度への寄与という観点からぬると、宇宙は 約 75\%のダークエネルギー、約 20\%のダークマター、約 5\% の通常の（原子を作っている）物質、そしてほんのわずかの 光子とニュートリノからできている。この值は、ビッグバン モデル、一般相対論、および、宇宙は最も大きなスケールで は一様であるという「宇宙原理」が正しいという仮定のもと に得られたものである。これらの仮定の裏づけとなる実験と 観測の広範さと緻密さは、この宇宙モデルが確固たる基礎の 上に成り立っているという自信を与えてくれる。

ダークマターが存在するという証拠は何か ?

私たちはダークマターを見ることはできないが、間接的な方 法でその存在を推測することができる（図 1)。ニュートン の法則によると、天体の質量はその衛星の運動によって求め ることができる。計算の結果、銀河団の質量はその銀河団を 構成する銀河の質量よりもずつと大きく、銀河の質量は銀河 を構成する星と星間ガスの質量を合わせたものよりもずつと 大きいと推定された。このことを裏づける証拠はほかにもた くさんある。その上、この余分な「もの」が通常の物質では ないと信じるに足る理由があるのだ。通常の物質がそれほど たくさんあったとしたら、ダークマター探しにやっきになっ ている天文学者たちの目から逃秃続けることはむずかしいだ ろう。また、ダークマターが通常の物質であったとしたら、 ビッグバンの名残の宇宙マイクロ波背景放射や、銀河や銀河 団の性質の中にはっきりした痕跡を残すはずだが、そのよう なものも見つかっていない。
銀河や銀河団といった大きなスケールではニュートンの法則 は破綻する、と結論することはできないのか ?

数十年前なら悪くない仮説だったかもしれない。しかし、観 測されている銀河や銀河団の運動を説明するためにニュート ンの法則に代わって構築される新しい重力理論は、重力レン ズ効果 (遠方の光源からくる光が屈曲する現象)、宇宙マイ クロ波背景放射、および宇宙の大規模構造に関する膨大な量 のデータも説明できなければならない。その理論はまた、太 陽系内で得られた精密な観測結果によって課せられる制限も 満たしていなければならない。

地球の近くにはどのくらいの量のダークマターがあるのか ? 私たちの天の川銀河の星の軌道速度から、地球の近くのダー クマターの平均質量密度は、1 立方センチメートルあたり陽 子 1 個の 3 分の 1 程度の質量であることが示唆される。こ の数字は宇宙の平均密度の $10^{6}$ 倍の大きさであるが、水の 平均密度と比べると 24 桁も小さい。ダークマターが何から できているにしても、銀河の重力ポテンシャルの井戸の中を 星と同様に運動しているため、その速度は毎秒 200 キロメー トル程度であることがわかる。また、地球は太陽の周りを回っ ているので、地球に入射するダークマターの量には夏と冬と で約 10\%の差があるはずだ（図 1)。さらに、銀河のダーク マターの分布は滑らかではないかもしれない。銀河の形成は 現在も進行中であり、計算機を使った研究からは、ダークマ ターの固まりや潮汐力による流れといつた下部構造がかなり あるかもしれないことが示唆されている。 


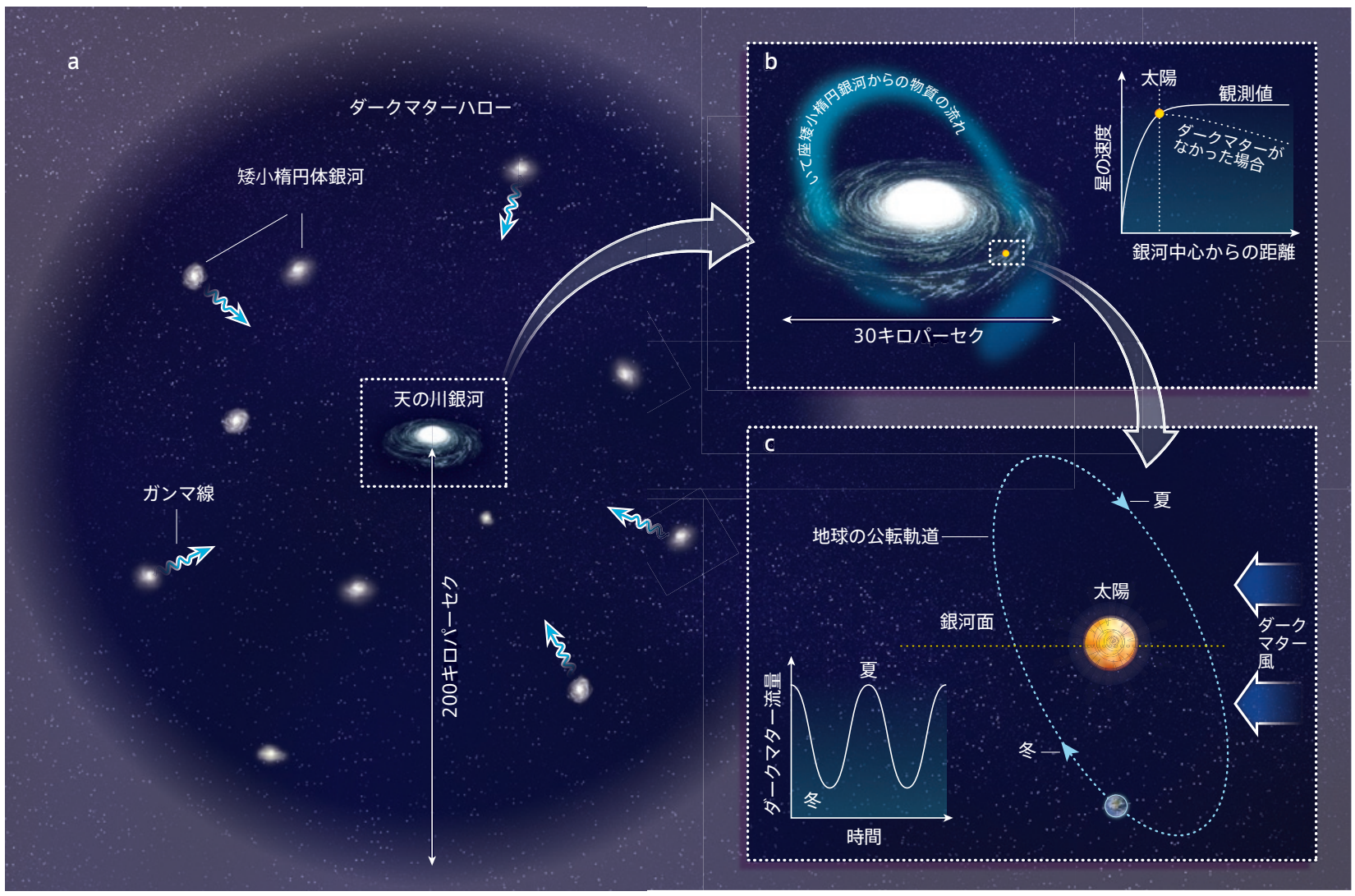

図 1 ダークマターとその検出方法。a、b、私たちの天の川銀河を構 成する星とガスの回転速度から、この銀河が半径約 200 キロパーセク (1 パーセクは約 3.26 光年) のダークマターハローに包まれているこ とがわかる。近隣の矮小楕円体銀河や、ダークマター密度が高いと予 想される銀河中心近くでのダークマター粒子の対消滅によって、高エネ ルギーのガンマ線が生まれている可能性がある。いて座矮小楕円銀河 から引きずられ、天の川銀河にからまっている物質の流れの中でも、ダー クマター密度は高くなっているかもしれない。c、地球は銀河のダーク マターハローの中を通過している。ダークマターを直接検出しようとす る実験で検出されるダークマター流は、地球が太陽の周りを公転してい るために季節によって変化する可能性がある。ダークマター流は、地球 が銀河ハローからのダークマター風と同じ方向に運動するとき (冬) の ほうが、ダークマター風と逆向きに運動するとき（夏）よりも小さい（約 $10 \%$ 減）と予想される。

\section{ダークマターの正体に関する最も有望な仮説は何か？}

ダークマターの正体については無数の仮説が出されている が、最も有望なのは新しい素粒子を考えるものである。長年 にわたる理論的検討に耐えてきた候補としては、WIMP（弱 い相互作用しかしない質量のある粒子) とアクシオンがある。 WIMP は、ニュートリノのように通常の物質とは弱くしか 相互作用しない素粒子であり、素粒子物理学の標準模型への 拡張（例えば、超対称性理論や余剰次元モデル）の中で自 然に現れてくる。WIMP の検出は、スイスのジュネーブ近 郊にある欧州原子核共同研究機関 (CERN) に建設された大 型ハドロン衝突型加速器 (LHC) の最重要目標の 1 つであ る。もう 1 つのダークマター候補であるアクシオンは、陽 子や中性子の中のクォークを結びつける強い相互作用の対称 性の一部を説明するために仮定された素粒子である。ダーク マターの正体についてはほかの可能性もあり、偏見のない心
を保つことが必要である。しかし、ダークマター粒子と通常 の物質との相互作用の強さ、ダークマター粒子の崩壊に対す る安定性、その「冷たさ」(今日のダークマター粒子は、光 速よりも遅い速度で運動しているはずである）などの制限に よって、可能性を絞り込むことができる。

ダークマターの正体を知るには、どういった実験や観測が有効か ? ダークマター問題に対する最も説得力ある答えが、ダークマ ター粒子の直接検出であることは明らかだ。銀河の周りには ダークマターが薄く広がったハローがあるが、このハローを 構成する WIMP が地球に飛んできて検出器内に入り、これ に衝突された原子核が反跳すると、検出器内に $10 \sim 100$ キ ロ電子ボルトのエネルギーが残ることになる。現在、こう した反跳原子核の観測により WIMP を検出しょうという実 験計画が約 20 ある。一部の検出実験では金属結晶中に標的 
原子核があり、原子核の反跳は検出器内で集められた反跳工 ネルギーを通じて検出されるようになっている。このような ダークマター検出実験では、地球上の自然放射線のバックグ ラウンドからダークマターのサインを見つけ出すことが課題 となる。しかし、今日の実験装置の感度は十分に高くなって きており、まもなく、ダークマターの主要な素粒子物理学モ デルのいくつかにつき、その当否を調べることが可能になる 予定である。LHCで未知の粒子が発見されればダークマター 候補の範囲を大きく絞り込むことができ、私たちは正しい道 筋にいることを確信できるようになるだろう。しかし、だか らといって宇宙物理学的なダークマター検出の必要性が否定 されるわけではない。

ダークマターを検出したという報告はすでにあったのでは？ 確かに検出したという報告はあった。イタリアのグランサッ ソ国立研究所の地下深くで行われている DAMA 実験は、地 球がその公転軌道によって銀河のダークマターハローの中を 運動していることに起因するとみられる、ダークマター流の 年間変動を検出したと報告した。このシグナルは、まだほか の実験によって裏づけられていない。ほかの実験は異なる 標的原子核を使っているため、さまざまな実験結果は特定 のダークマター理論の文脈でしか比較できない。DAMA 実 験の結果を説明するために、最も単純な超対称理論に現れ る WIMP の質量および通常の物質との結合が提案されたが、 これらはほかの実験によって否定されている。

\section{図 2 宇宙の膨張の加速とダー} クエネルギー。白色矮星の爆発 により生じる I a 型超新星は、標 準光源（明るさがわかっている 天体）であると考えられている。 この性質のため、地上から超新 星を観測したときの見かけの明 るさから、その距離を決めるこ とができる。天体が暗く見える ほど、その等級は高く、遠くに ある。ある後退速度をもつ超新 星が予想よりも暗いという観測 から、宇宙の膨張は約 50 億年 前までは減速していたが、それ 以降、加速に転じて今日に至っ ていると結論された。このよう に宇宙の膨張が加速する原因は ダークエネルギーにあると広く 考えられている。

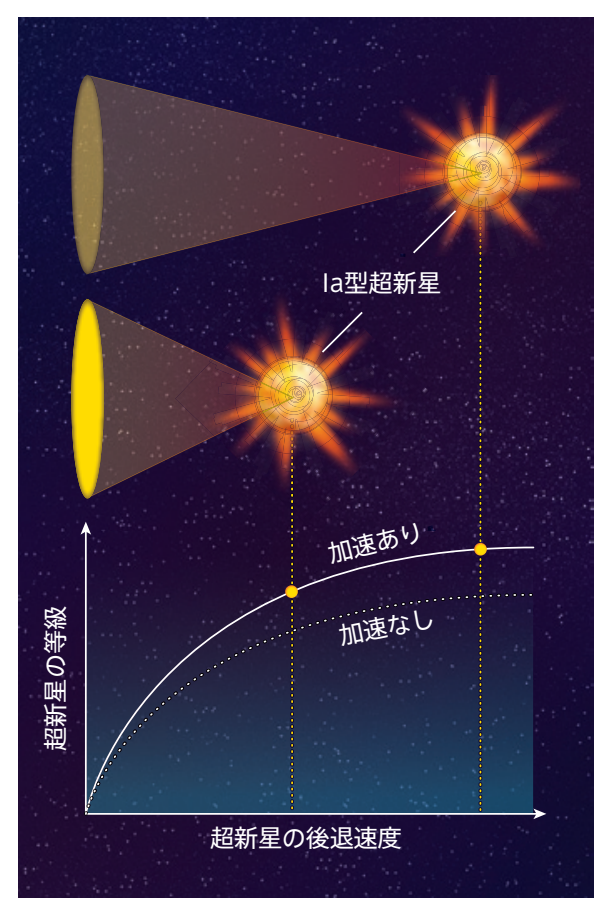

ほかの方法でダークマターを検出できないのか？

個々の WIMP は理論的には安定だが、WIMP の対は「対消 滅」することがあり、高エネルギーの光子と、陽電子（反電 子)、反陽子、ニュートリノの形の宇宙線が生成する。そう した粒子を検出できればダークマターの存在の間接的な証拠 になるかもしれない。対消滅生成物が地球の近くから来てい るならば、対消滅が起きている場所は、ダークマター密度が 高い銀河中心か、天の川銀河を取り囲み、主としてダークマ ターからなる、いくつかの矮小銀河の中心である可能性が高 い(図 1)。1つの手がかりは単一エネルギーのガンマ線で ある。これらの手がかりを探すために、多数の地上実験、気 球実験、衛星実験が行われている。

\section{宇宙線実験の現状は?}

2008 年、観測衛星 PAMELA を使った宇宙線実験と気球を 使った ATIC（高度薄型電離カロリメーター）実験から、高 エネルギー宇宙線陽電子の流量の超過が報告された。この観 測結果は WIMP 対消滅が原因である可能性があるが、観測 された流量は単純な WIMP モデルが予測するよりも数桁大 きい。1 つの解釈は、WIMPダークマターはこれまで考えら れていたよりも複雑であるというものだ。しかし、この異常 の原因がダークマターにあるとみなす前に、もつと平凡な宇 宙物理学的説明（地球近傍のパルサーによる粒子加速など） の可能性を除外しなければならない。

\section{ダークマターの今後の研究計画は ?}

ダークマターを直接検出する実験は、WIMP の「風」を利 用して (図 1)、地球起源のバックグラウンドシグナルから WIMP 流の特徵的な年間変動を分離することをめざしてい る。一方、近い将来に打ち上げられる欧州宇宙機関 (ESA) の天文衛星ガイアは、地球近傍の $10^{9}$ 個の星の位置と運動 状態の地図を作成することになっている。この地図を使って 天の川銀河の重力場を描けば、ダークマターハロー内のダー クマター分布を推測することができるだろう。また、WIMP 対消滅から生成したガンマ線を探す実験もいくつか計画され ており、最近打ち上げられたフェルミガンマ線宇宙望遠鏡を 使う実験もその 1 つである。南極のアイスキューブ・ニュー トリノ天文台などの高エネルギーニュートリノ望遠鏡は、太 陽や地球に蓄積した WIMP の対消滅から生成したニュート リノを探すことになる。

\section{ダークエネルギーとは何か ?}

通常の物質どうしは重力によって引き合うため、宇宙の膨張 は減速するように思われる。けれども、観測によると宇宙の 膨張は加速しており（図 2)、私たちの宇宙の理解がまだま だ不足していることを示唆している。この観測結果の解釈と 
して有力なのは、宇宙は「反重力」効果を及ぼす何かによっ て満たされているとする説であり、この「何か」はダークエ ネルギーとよばれている。ニュートンの重力理論では重力が 反発作用を及ぼす可能性はないが、一般相対論ではその可能 性がある。物質とエネルギーの等価性から、分子の熱運動に よるガス圧が重力場の源となりうるのである。十分な負の圧 力をもつ流体の重力場は反発作用を及ぼす。分子運動が負の 圧力をどうやって引き起こすのかイメージすることはむずか しいかもしれないが、素粒子理論に現れる量子場の一部は、 負の圧力をもつ流体の存在を可能にすることがわかってい る。つまり、ダークエネルギーとは単に、宇宙の膨張の加速 を説明するために仮定された、負の圧力の流体のことなのだ。

\section{ダークエネルギーの候補として最も有望なものは何か ?}

ダークエネルギーの候補として最も単純なものは、アイン シュタインの宇宙定数である。宇宙定数は、負の圧力をもつ 完全に一様な流体を表しており、宇宙の最低エネルギー状 態 (真空状態) と関連づけられている。しかし、観測から要 請される宇宙定数の值は、理論的な予想值の $10^{120}$ 分の 1 に しかならない。ダークエネルギーのもう１つの有力候補は、 アクシオンに似ているが質量はもつと小さい、未知の粒子の 流体である。量子理論は、そうした粒子は宇宙の膨張の加速 に必要な負の圧力を供給できると予測している。

\section{既知の重力の法則は宇宙スケールではどれほど信頼できるのか ?} 一般相対論はうまくいつている。一般相対論の正しさは太陽 系内の事象で詳細に試された。さらに、膨大な量の天体物理 学および宇宙論的観測結果が、この理論に基づいて理解され ている。しかし、一般相対論がこれだけうまくいっていても、 宇宙的な長さのスケールにおける重力理論に変種が存在しう る可能性は否定されない。宇宙膨張の加速を説明するために、 重力理論というパンドラの箱が開かれ、多数の理論が提案さ れてきた。しかし、太陽系内の観測結果から課せられる精密 な制約に反することなく重力理論に手を加えることは、驚く ほどむずかしいことがわかりつつある。そして、今のところ 説得力のある代替理論はでていない。

\section{ダークマターとダークエネルギーが関連している可能性はあるか？} 素粒子物理学の標準模型を超えて、ダークマター粒子とダー クエネルギー場を含めた「暗黒部門」が存在する可能性を考 えてもおかしくないように思える。いずれも未知の重力場源 の存在を要請しているようだが（1 つは引力、もう 1 つは斥 力作用を及ぼす)、今のところ、2つの現象を統一的にうま く説明する提案はなされていない。

宇宙の加速がほかの現象に起因している可能性は ?
新種の重力（通常の物質がダークエネルギーと同じ反重力効 果を生み出すような重力）や新しい電磁気的効果（遠方の超 新星を暗く見せるような効果。図 2 参照）が存在すると考 える人や、私たちの基礎的な仮定（最大の長さのスケールで の宇宙の統計的な一様性や等方性）に何らかの欠陥があると 考える人もいるかもしれない。現在までの観測結果は、こう した提案のどれかを特に支持しているわけではないが、私た ちは偏見のない心を保たなければならない。

\section{最近の観測でダークエネルギー問題の精密化に役立ったものは?} 「バリオン音響振動」の観測は、宇宙の加速を裏づけ、精密 化するのに使われた。バリオン音響振動は宇宙初期の音波に よって作られたさざ波であり、宇宙マイクロ波背景放射と銀 河分布に刻从込まれている。このさざ波の波長が地球からの 距離とともにどう変化するかを測定することにより、宇宙の 膨張の歴史を図で表すことができる。

ダークエネルギーの正体を知るためにはどんな実験が役立つか ? 今日、宇宙の加速膨張という現象を説明できる説得力のある 理論が明らかに欠けている。だから、これまでの研究では、 何らかの手がかりがひょつこり現れるかもしれないと期待し つつ、同じようなデータが集められてきた。現在、超新星や バリオン音響振動を使う方法のほかに、加速膨張する宇宙に おいて通常の物質とダークマターが重力の影響下で集まる速 度を測定するという方法での研究も進められている。1つの 有望な方法として、弱い重力レンズ効果を使ってダークエネ ルギーへの制限を設けるというものがある。強い重力レンズ 効果では、遠方の光源からの光が前景の物質 (レンズ) によっ て強く曲げられ、光源の像が強くゆがみ、弧の形に引き伸ば される。一方、弱い重力レンズ効果では、光源の像はわずか に伸び、拡大されるだけである。もう 1 つの方法は、銀河 団の高温ガスの X 線放射を使い、その重力ポテンシャルの 井戸の深さを決定するというものである。こうした方法は有 望視されているものの、宇宙の加速膨張の基礎にある物理を 決定することはむずかしいかもしれない。一方で、このよう に困難で基礎的な問題に取り組むためには、ほかに方法がな いようにも思える。

Robert Caldwell、ダートマス大学 (米)

MarcKamionkowski、カリフォルニア工科大学（米）

\section{さらに深く読みたい方へ}

- Caldwell, R. \& Kamionkowski, M. the physics of cosmic acceleration. Annu. Rev. Nucl. Part. Sci. (in the press); preprint available at http://arxiv.org/abs/0903.0866 (2009).

- Frieman, J. a., turner, M. s. \& Huterer, D. Dark energy and the accelerating Universe. Annu. Rev. Astron. Astrophys. 46, 385-432 (2008)

- Hooper, D. \& Baltz, e. a. strategies for determining the nature of dark matter. Annu.

Rev. Nucl. Part. Sci. 58, 293-314 (2008).

- Hogan, J. \& Brumfiel, G. Unseen Universe. Nature 448, 240-248 (2007). 